\title{
Breeches of Conduct: A Piratical Ficto-Criticism
}

\author{
Coralie A. Clark
}

Breeches of Conduct: A Piratical Ficto-Criticism de Coralie Clark est une critique de l'histoire d'une femme pirate du 18e siècle «dont l'identité et le sexe doivent demeurer secrets pour assurer sa survie». Parsemé de citations percutantes, le texte de Clark explore l'espace que les femmes ont dî "envahir» afin de se distancer des légendes patriarcales pour se forger leur propre histoire. Commentant la vie des femmes qui vécurent sur les mers ou près des zones côtières, Clark étudie les femmes qui brisèrent les traditions en s'attaguant directement au monde traditionnel et en violant des hommes. En même temps, elle écrit l'histoire d'une femme - une pirate qui résiste à son statut de femme de soldat ou de femme de pêcheur. Comme les hommes dont elle se moque, son personnage commence à voir les fermmes comme des sous-humains ou des créatures se mouvant comme des oiseaux bruyants. À propos d'une femme capturée au bord d'un bateau, le personnage de Clark dit: "Elle est le butin. Elle est le cadeau. Elle est la cargaison. Elle est la commodité. Elle ne peut s'échapper de ses chaînes. Enlacée. Attachée.» Dans cette fiction, Clark explore et critique le poids énorme de l'histoire patriarcale. Elle insiste aussi sur la gravité de la condition féminine. Habillée comme un hornme, le personnage de Clark insiste: "Je n'existe pas sur la carte, je ne suis pas au premier plan» puis: "Je sais néanmoins frapper un homme par derrière avec un coutelas. Je n'ai pas de barbe, et mon cou oulnérable est offert à l'étranglement du marin. Je dois grignoter pour survivre car quand un marin m'attrape par le cou, je n'ai aucune chance.» En effet cette histoire fait état du choix du personnage.

At night, I lie upon the deck of our brazen sloop and count the constellations of spots on my body, gathering them like coins under my fingernails. I look for aberrations, the pocks and welts, the first tracings of death. I run my fingers over the grazings of cutlasses and the burn of rope. Oh, to be the figurehead, shirt open to the wind! I keep my body tightly swaddled. A lift of the sleeve. The arm inspected. A button unhooked, then hooked again. Lacing untied, a hand slipping in to scratch. Then bound again. The figurehead stares ahead, all-seeing, skin 
cracks, dries, crusts with salt, crawls with wood-worm, a shibboleth of weevil tracings. S/he cannot scratch, just puts $h$ face unflinching into the wind.

I am the sailmaker and the physician on this pirate sloop. No one inspects my body. I saw off legs with gusto, whistling ${ }^{1}$ like the ship's cook splitting a chicken while I work.

"Unfortunately, illness and examination by a doctor often caused. cross-dressed women to have their identity exposed. Any woman who wanted to keep her sex secret would have to choose silent suffering or the untutored assistance of a collaborator" states Jo Stanley in Bold in her Breeches: Women Pirates Across the Ages (166). My character must be a physician, or suffer miserably.

I have no name, no name to you. Miranda? Margaret Barclay? Mother Carey? Elspeth MacEwan? Maria Cobham? Bessy Miller?² I have no name to you.

But it is not for you I write: it is by you, passing through you, because of you--And thanks to you each book takes every liberty...This book is not a narrative, it is not a discourse, it is a poeti$\mathrm{cal}$ animal machine, the grain of its skin is pure poem. Because you keep watch, this book gives itself the freedom to escape from the laws of society. It does not fit the description. It does not answer the signals. It does not get a visa.

- Helene Cixous, Stigmata: Escaping Texts (150)

I am not on the map. I am not on the frontispiece. Captain Charles Johnson is the gatherer of facts, the miner of truths. He has written my story, along with that of Captain Rackam, "Calico Jack" to us, Anne Bonny, and Mary Read.

Johnson has disappeared to history, but his story remains, and through his story my remnants can be found, obscured. That Johnson told my tale untruly shows only the success of my deceit. I will salvage my story from his.

What possibly could be considered feminist about salvaging which has all sorts of legalistic associations having to do with saving cargo or ships from marine peril?

- Daphne Marlatt, Readings From the Labyrinth (156)

I circumvent the world on my tangential journey. 
Captain Johnson tells the tale of Rackam and Anne Bonny, bound in love. And Mary Read, bound to Anne. Bound together, bound for England, bound to Jamaica. Bound in the pages of A General History of the Robberies and Murders of the Most Notorious Pyrates. There I am, in his words, I will point you in the way. The tale is told of how Rackam would capture ships belonging to Jamaica, and any crew of use to his company would be forced to join the pirates.

Among them was a young Fellow, of a most ingageing Behaviour, or, at least, he was so in the Eyes of Mary Read, who became so smitten with his Person and Address, that she could neither rest, Night or Day. (123)

That she was smitten is true enough, but that I was a young fellow, well, that isn't known for certain (Klausmann 215). That Anne Bonny and Mary Read were the only women sailing as pirates, isn't either. What is known only is that they were found out, and if it weren't for me, they'd have swung from the gallows. I was never found out, captured, yes, but never sold as a pirate.

What we salvage refers to that which is actually still usable although it has been written off as lost or irretrievable, or irretrievably damaged... What interests me as a feminist writer is the concept embedded in this world of retrieving value from what has been written off...

- Daphne Marlatt, Readings From the Labyrinth (156)

I started my seafaring life from the shores of Kirkcudbright in New Galloway. My mother had been a sea-witch selling the wind to sailors. She worked from the South West of Scotland, near Dumfries, in the area on the map known as the witch's chin. She sold rope tied into three knots to bring wind to the sails of ships (Klausmann 14). She sold what was at the same time nothing, and everything, as I would soon learn when I began my seafaring days.

And so I scavenged. Scavenged the ships that dashed on the rocks.

I made my living on the shore, on the margins of the sea, as a scavenger of wrecks. I learnt to heal my own wounds, scrapes from barnacled rocks, the cuts from the blue razor mussels that mount rocks like soldiers. I harvested sea-lettuce and mermaid's hair. Everything we needed for survival came from the sea. 
Perhaps my grandmother was a selkie, ${ }^{3}$ and that is what they say about me now, that I have returned to my home in the sea. Had I always had a desire for a pelagic life?

Daniel Defoe moved to Kirkcubry (Kirkcudbright) in 1726 and of the town observed the following:

Here is a pleasant situation, and yet nothing pleasant to be seen. Here is a harbour without ships, a port without trade, a fishery without nets, a people without business; and, that which is worse than all, they do not seem to desire business, much less do they understand it. I believe they are all very good Christians at Kirkubry [Kirkcudbright], for they are in the very letter of it, they obey the text, they are very contented with such things as they have. (West 376)

A pleasant situation indeed we had, and for that he can be credited, but to say it was a harbour without ships was not entirely true, it was just that most of the ships lay at the bottom of the harbour; their spines litter the sands like herringbones. ${ }^{4}$ We have a business, we all have a business, and some of us are better at it than others. Some of us smuggle, some of us scavenge, and we make it a village affair. Some of the men with chests like barrels are best for picking up the larger pieces of wreckage, and the ones that swim set out after the bobbing kegs, but it is the lithe women and children that can skip over the rocks and slip into the caves $^{5}$ where the goods are kept until they can be smuggled out.

My father is a fisherman, my mother a fishwife, but at times the ocean did not give us fish, and so my mother took to the harbour as a windmerchant. But the ocean did give us barrels of rum, and green glass bottles of liquors. The whole town took its livelihood from the sea, and at times there was much for all, and much celebration, and sometimes the sea offered little, and we were a wretched bunch. We'd sit along the harbour walls and dangle lines for crabs. ${ }^{6}$

They appear dejected and discouraged, as if they had given over all hope of ever being otherwise than what they are...

- Daniel Defoe (West 377)

Stanley posits that wrecking, or luring ships from shore into rocks, was a community endeavour, with women and children participating. Precious cargo ranged from the mundane to the extravagant: "fruit, flour, 
tar, cork, deerskin, wine, coffee berries, saffron, indigo, licorice, rum or brandy" (134). Such wrecking parties are documented along the English coastal areas of Devon and Cornwall, and in 1817 Rev. G.C. Smith made the following observation, a scene undoubtedly reminiscent of similar ones that took place in the previous centuries:

Thousands of people are instantly collected near the fatal spot...men, women and children are working on here to break her up by night and day. The precipices they descend, the rocks they climb and the billows they buffet to seize the floating fragments are the most frightful and alarming I have ever beheld; the hardships they endure, especially the women in winter, to save all they can, are almost incredible. (Stanley 134)

It all started around the time a scholarly gentleman of odd habits came to town. He said he wanted to set up a business in the area. Every morning at low tide, he could be seen at Doune beach scavenging the shores not for limpets and mussels, but for empty shells and dried out starfish, bits of sea-glass and pebbles. I never minded him, but I kept an insouciant gaze on him, as he did me (this is not my voice, I have no voice, never had a voice, lost like a siren's call. If I had a voice it would be like this perhaps: Ar, matey, ye scurvey dog!). The townsfolk suspected he came from a custom house, here to spy upon our little town. He didn't seem to do much but commune with the ocean in his solitary pacing, much like a wind-battered heron, arms clasped behind his back, knees knocking on long skinny legs. Although a large ring glinted on his finger, the buttons on his coat hung precariously from thin threads. He was forever caught in the arc of sand between the two rocky outcrops, pacing back and forth, his shoes made for the city, not the shore, for he could not scramble over rocks, and if caught by a wayward wave, he would leap back lest the salty brine mar the leather. One morning he chased after the tide to catch a piece of dark green glass, and driven by a hushle of wind, an errant wave chased him back to shore. He scurried backward like a crab, heels sinking into the wet sand and fell right onto his backside, soiling the tails of his frock-coat.

"You, young boy, why stand laughing at me?"

At first I did not know it was I he addressed (did I snicker?), but that morning only a few fishermen could be seen far along the shore pulling in their morning catch. I scampered down the rocks and gave him my 
forearm and pulled him up.

- foreground, fore-body, carrying these forward parts of our bodies. Ladies do not draw attention to themselves...ladies keep to the background. ladies are the soothing background their men come home to.

- Daphne Marlatt, Ana Historic (34-5)

He asked me my name, and I gave it to him. He told me, being new to these parts, that the name sounded strange to him, and asked me to spell it out for him. I told him I could not spell it, only say it. He made me say it three more times, and then he took up a stick and made scratches in the sand, which he said was my name. Geoghan. ${ }^{7}$ I do have a name. I've been telling you stories. He showed me how to form the letters and said it was a right disgrace that the town did not have me sent to school, and in England there were many fine schools, and some in Edinburgh as well. I said many of the boys from our village had gone to the city to seek their fortunes, to become apprentices and merchants, but my life was tied. Tied to the sea. He then looked at me strangely and went on to say that the Indies lay at our feet, and England and Scotland together had the world at their feet, that once the threat of Europe lay to the East, but now the hope of the future was to the West. He looked at me shrewdly and for a moment I felt he had guessed at my true nature, but in my breeches and shirt, my hair tied back behind my ears like his, he only said, "are you a scavenger, a wrecker of ships?"

No woman shall falsify her sex by wearing a man's clothing. She subjects herself thusly to the strictest penalty that the Law or our Wrath may Ordain.

—Charles I of England, 1648 (Klausmann 204)

I made no reply, and he picked up the piece of bottle glass and began to weep bitterly. "This," he said, "is some wretched man's hopes and dreams, dashed upon the rocks," I said the glass was bottle-bottom still intact, and if he cared to give it over, I'd take it home to add to the window my brother was making. He then glanced out at the sea and said it was a miserable life being an honest man on the Ocean, and that the Captains of the ships were fierce men who made the lives of those beneath them a miserable lot. He told me tales of Pirate ships that preyed upon the honest business of men, and warned me from them. 
Pirates were a ruthless bunch of vagabonds, tying up honest men back to back and tossing them to sea. My friend cheered up with a shift of the wind, and shaking the sand off his breeches he asked me if I'd ever heard of salvaging with diving bells? He excitedly nattered on about plans he had to return to England, to Cornwall, to look into the manufacturing of such bells.

They have all the material for trade, but no genius to it; all the opportunities for trade, but no inclination to it. In a word they have no notion of being rich and populous, and thriving by commerce. They have a fine river, navigable for the greatest ships to the town quay; a haven, deep as a well, safe as a millpond...

- Daniel Defoe (West 376)

The next morning I ran down to the shore, my mother scolding me to come back and help her with the fish-scaling, but I knew all would be forgiven if I came back with a purse of mussels for our pot. I had my knife, and with a twist I could free shellfish from their imprisonment on the rocks. I could never free mussels without my thoughts turning to the two young women who refused to give up their Covenant and hence were walked miles across the sand, past the picked over midden of wrecks that lay draped in green seaweed, tied together back-to-back, and then left with stones around their ankles to await high tide, ${ }^{8}$ but unlike the mussels they had no shells to retreat to, and when the waters receded the next morning, no one in the village dared go out to scavenge, except the families of the two women, who stole out early to retrieve their bodies. One body could not be found, and the family took comfort believing she had been a selkie, and when the tide had come, changed form. By the sad cry of the gulls she was found many days later, as I found the strange gentleman's frock coat, bundled up and bound with a piece of sea-onion nestled in a rockpool. (Do you believe me?) Perhaps he was a selkie too, and returning to the sea, had no need for his coat and so made a present of it to me. Once I sewed the buttons on more firmly, it fit me fine.

But alas! There is not a vessel that deserves the name of ship, belongs to it; and, though here is an extraordinary salmon fishing, the salmon come and offer themselves, and go again, and cannot obtain the privilege of being made useful to mankind for they take very few of them. They have also white fish, but cure none; and 
herrings, but pickle none. In a word, it is to me the wonder of all the towns of North-Britain; especially, being so near England, that is has all the invitations to trade that Nature can give them, but they take no notice of it. A man might say of them, that they have the Indies at their door, and will not dip into the wealth of them; a gold mine at their door, and will not dig it.

— Daniel Defoe (West 376-377).

The sudden disappearance of the stranger, and my appearance in his frock-coat did not sit well with some of the townsfolk, and I had little choice but to leave.

Feminist sociological studies posit that women who break with traditional gender roles have "courage, impetus, an ability to be hard when appropriate, curiosity, a huge need for change and shrewdness to see and act upon opportunities" (Stanley 42).

The sea washed away my name from the sand, but I remembered how to write Geoghan, and so I later proudly signed my pirate articles Geoghan.

My mother was at a loss as to what to do with me. If I'm not married, she fears I will have the same fate as Elspeth MacEwan, and yet she was at a loss as to who would take me. I could go to the city and work in one of the merchant houses, but the thought of leaving the sea put me in a state of despair.

Stanley notes that "given the precarious nature of making a living and women's responsibility for fending off starvation, it can be seen how and why coastal women would be drawn into piracy and wrecking. They could not afford the luxury of conforming to distant ideas about respectable womanly behaviour" (135).

For a decent lady kept herself well-covered, her sexuality hidden. - Daphne Marlatt, Ana Historic (33)

In seventeenth- and eighteenth-century Irish coastal communities, the women organised fish markets and owned their own boats, and in the town of Claddagh near Galway, took part in "wage protests and demonstrations on behalf of absent husbands" (Stanley 128). Stanley concludes that the women of these communities were spirited, and many married pirates, or cooperated with pirates, understanding their boundaries. For some women, it was not enough to stay in bounds.

Why? 
Did I seek adventure?

Did I seek fortune?

Did I want to avoid marriage?

Did I want to avoid prostitution?

Did I want the company of men?

Did I want the company of women?

Was it to avoid Boredom?

Why?

Because...

Nothing ever done, over, finished. The litany of the Western Canadian farm family. All hands on deck, either in field or barn, working. And then there were always the dishes.

- Aritha Van Herk, In Visible Ink (158)

"What do all of these reasons have in common? Breaking out of structured obedience, pre-set orders and moral unities; escape from assigned roles, authoritarian hierarchies, and perpetually expanding apparatus of control and supervision; in short, everything that reeks of an increasingly powerful bourgeois society," writes Gabriel Kuhn. "Instead, there is a plunge into a world of unpredictability, danger, excitement, excessive living, fast death; of war, adventure, hunt, dance, fighting games, and everything that strong, free, cheerful action implies" (Klausmann 229).

I set off soon after that to join the seafaring life, and to make my way as a pirate, despite the warnings of my friend. My brother had left to become a soldier, and what was left for me but to become a soldier's wife, or a fishwife? I could not entertain thoughts of any other livelihood, other than the one I had, scavenging at the margins, on the side, with the children, the elderly, the women, and I could not get my mind off the Indies my friend had spoke of. From my little rowboat I looked through the clear waters and saw caravans of moon-snails journeying across the sands, and I too wanted to set off for adventure.

I stole away in the night. A smuggler's skiff bringing rum from a sloop back from Jamaica came into harbour one night. The rum passed from lad to lass, I at the lead. When the last barrel was set down I hoisted myself into the boat and asked the sailors if their sloop truly be pirate, and begged the sailors to take me to their skipper. I wore my new greatcoat, breeches, and straw hat, and they laughed at my attire and said if I would swear on my life to the articles, I could come aboard. 
It was a passive life I left behind. When I think back to it now, there were not many times I can picture the town without the sight of the church fathers, burnt-candlewick men on their solemn march to the Kirk. My mother had witnessed the burning of Elspeth MacEwan, ${ }^{9}$ and forever said it was not safe for women to live alone. My knowledge of medicine and weather which I gleaned from her and her mother before her put me in a precarious position, for even though the witch burning had stopped, we lived in fear of a revival. So it was my own mother who dressed me in breeches and let me run wild among the gulls, rocks, sand, pools, caves and let me live as a boy, so I knew no life like it and wanted none other. Yet as I grew taller, she called for me and not my brother, and sat me by the hearth with needle in hand.

Now I sew calico patchworks of sailcloth and flesh.

We are sailing for the West Indies and I check my body for old wounds opening. ${ }^{10}$

The waves tip our sloop back and forth, and at the best of times the sea is smooth as a piece of silk and our sloop skims along by the wind. When the waves crest their highest and lift me to the heavens I lie on the deck and feel the perfect syzygy of the sun, the moon, the deck, the crew below, our boat and the ocean gently rocking us along.

Our little sloop, our bobbing cork, is the apex of the world. We are sailing for the West Indies and I consult the stars caught in the welkin fishnet at night for our direction; in the day I watch for the skin of land on the horizon.

We have cargo on board, and gifts. We have silks, spices, gold. All robbed. Our little sloop with 20 cannons can latch on to a passing Galleon in the night like a fish on the side of a whale. Our pantaloons are thick with pitch, as is our mealy skin. I know where to nick a man in the neck with a cutlass. I have no beard, and my throat is vulnerable to the sailor's grasp. I have to be nimble to survive, for once a sailor gets me 'round the neck I will not stand much of a chance. The eyes and the neck are the targets in hand-to-hand fighting, when the cutlasses have been cast down. I have found other regions of vulnerability on a man's body. I may be small and short, but I have held my own so far. When we sail near Jamaica, into the clear, shallow waters, those that can strip down and dive and rub sand into their skin.

For many low-wage sailors and those eking a life from the shore, piracy was the opportunity to get a share of the immense profits amassed 


\section{$76 \cdot$ Tessera}

through the circulation of trade. According to Stanley, captured cargo vessels loaded with indigo, silk, linen, silver, gold, wine and brandy, linen and cotton could yield up to 100,000 pounds. Stanley reports that Sir Frances Drake, as a privateer, made 4,700 percent profit in a single journey, and in another instance, pirates on Thomas Tew's ship in 1693 made 3000 pounds each from the capture of a Bombay merchantman in the Indian Ocean. Stanley succinctly sums it up: "It would take three lifetimes for a regular seafarer to earn this sum" (142).

There are days when the wind does not come and I think back to my mother and her wind-knots. The sun blisters our skin and my fellow seamen start fighting like dogs. Or cocks. I am aware of being the sole hen, and so I have developed a sharp tongue and I am quick with my knife. I am small in stature, but with strong arms like a milkmaid. When the wind leaves for another lover, we are left with little to do. I whittle bits of bone and wood into amulets. If I saw off a leg, or an arm, I lay claim to the appendage, take what is mine, and so round my neck hang the beads and charms of the bones of my shipmates. It is during these times too that music and dance take place. We lie in each others arms and I braid bone beads (Jack Thomas's toes) into the greasy coils of my shipmates, and ribbons of lace and calico. We are a pretty bunch of pirates, and when we dance, we wrap swags of calico and silk around our waists and spin like ladies at a ball, ${ }^{11}$ and it is nothing like the dour life I left back on shore.

They are, indeed, a sober, grave, religious people, and that more, ordinarily speaking, than in any other part of Scotland; far from what it is in England; I assure you, they have no assemblies here, or balls.

\section{— Daniel Defoe (West 377)}

Cross-dressing on ships served a number of purposes. Mainly, it was considered bad luck to have a woman aboard a ship, although many women did seek passage on ships, or as officer's wives, travelled openly. Protection could be afforded to those of higher status, such as the officer's wives, and conversely, those of low-status had the protection of a certain anonymity. One suggestion is that "seeing women dressed as men, however notionally, might have enabled the superstitious to dodge the idea that they were bad luck on board, as well as giving a clear sign they were not sexually available to the entire crew" (130). "Lust overrode 
qualms" (129) in many instances where women came on board. Breeches were much more practical than skirts for maneuvering on ships.

However, as much freedom as the wearing of breeches offered, notes Stanley, it was still women conforming to the male attire: "[Pirate-life] offers isolated women a sense of belonging to what can be a suprisingly loyal and kind group, even at the price of conformity is to standards not theirs" (146).

We lie in each others arms and pick lice from our hair and clothes. A ribbon is untied, and then tied. A knee is shown, and then covered. A piece of lace is fixed to the collar. A crimson sash wrapped around a waist. A piece of fine cotton kilted over buttocks. And we dance, and sing, and look very pretty indeed. A patch is fixed over a missing eye. A patch is fixed to a cheek. A wooden leg is lathed and polished and fixed to a straw shoe. Indigo is scrimshawed into flesh. Writing on the body. The skull and crossbones. The Jolly Roger. Earlobes, noses, fingers strung like current berries and decked around our necks. And we fight, and curse, and look very fearsome indeed. ${ }^{12}$

I have sought...to acknowledge the right of the subordinate class...to make something of what is made of (them) - to embellish, decorate, parody, and wherever possible to recognize and rise above a subordinate position which was never of their choosing.

— Dick Hebdige, Subculture (138-139)

Like their colourful costumes, language and outrageous dexterity with a sword, they are a reminder that sexual difference is largely a masquerade.

- Stanley, Bold in her Breeches (198)

There is some strange cargo on board. It is in the Captain's hold. It rustles and moves like a bird caught in a granary. I cannot see it, for when I put my eye up to the keyhole, I obscure all light. If I stand back a bit and peer in from a distance, I can make out the flutter of white, and the movement of copper skin like a silkworm in a cask of spun thread. My eyes sting and water from peering, like the eyes of some of our crewmen when they say good-bye to their loved ones on shore, or so-long to their shipmates when they chance to leave their galleons for our little pirate sloop. Our figurehead puts $h$ face to the wind with nary a tear in h eye.

Once I peered in through the keyhole and an eye peered back at me. 
She is the Mogul's daughter, caught in our raid on the Mogul's ship. She is to be the Captain's bride. Land ahoy! Lower the anchor! She is anchorite, walled up in the Captain's hold. She is the prize. She is a gift. She is cargo. She is commodity. She cannot escape her trappings. Laced. Bound.

None of these bold Adventurers were so much talked of, for a while, as Avery... and was looked upon to be a Person of as great Consequences; he was represented in Europe, as one that had raised himself to the Dignity of a King, and was likely to be the Founder of a new Monarchy; having, as it was said, taken immense Riches, and married the Great Moguls Daughter, who was taken in an Indian Ship, which fell into his Hands; and that he had by her many Children, living in Great Royalty and State. (Johnson 25)

I see land. Land ahoy. Land a ho! I see land. Figurehead, do you see it too? Wood-worms trace tear-tracks on your cheeks. I see land. Land for us to plunder, pillage, partake of and take from.

Stanley notes that acts of pirate violence refer to women generally as victims, but what of women travelling as pirates? Stanley states that instances of "mass-slaughter, enslavement and depredation are not so much pirates being wickedly piratical as European men doing what Europeans did in places they thought they had a right to despise" (132). Furthermore, "the ideology that engendered slavery enabled white people, especially from imperial powers, to think that everyone else was Other and lesser" (153); a "shared gender did not bring humanity but that any human body was disposable" (154).

The islanders are swimming and rowing out to meet our ship.

The enormous weight of male story, male measurement, male domination. It's our turn to create some male Madame Bovarys and Anna Kareninas and Molly Blooms. Not appropriation but quite a different matter, a righting of the balance, an equalizing of the scales. I believe we are free to create as many bastards and sweethearts and saints and gentlemen and deluded idiots as there are such configurations among men. To revise the overall story, from our point of view.

- Aritha Van Herk, "Of Viscera and Vital Questions," Language in her Eye (272) 
The average pirate lasts two years. What is my fate?

What did Captain Charles Johnson have to say? What could he say? He tried to give an honest account of the trial of Rackam and his crew:

Two other Pyrates were try'd that belonged to Rackam's Crew, and being convicted, were brought up, and asked if either of them had any Thing to say, why Sentence of Death should not pass upon them, in like Manner as had been done to all the rest; and both of them pleaded their Bellies, being quick with Child, and pray'd that Execution might be stay'd, whereupon the court passed Sentence, as in Cases of Pyracy, but ordered them back, till a proper Jury should be appointed to enquire into the Matter. (Johnson 117)

Mary Read was a pirate on a sloop that captured our little sloop. Yes, I was that engaging fellow that she became so smitten with. Each night we would sit together under the stars and talk: "She first insinuated her self into his liking, by talking against the Life of a Pyrate, which he was all together averse to, so they became Mess-Mates and Strict companions" (Johnson 123). I never felt averse to the Pyrate life, but questioned on trial in Jamaica, I certainly pleaded the case.

Did she discover I was a woman? Did I discover she was a man? Of course, but Johnson never discovered my true nature. Mary "suffered the Discovery to be made, buy carelessly shewing her Breasts, which were very White." A lace untied, and then tied again. Skin mealy and smeared with pitch. And then another lace untied, and then tied again.

A fight with my crewman started over a piece of bone I was carving for Mary. The messmate was a burly fellow, new two days to the ship, and ready to establish his dominance. A young, hairless boy with a gift for carving was an easy target and the bullying began. My knife came out and we exchanged words, but as we were at anchor the duel had to be fought on land. "When Love once enters into the Breast of one who has any Sparks of Generosity, it stirs the Heart up to the most noble Actions" (Johnson 124). Had exposing her breast caused Mary to expose the soft, womanly side of her nature? Johnson would have you believe it was so, but she was the woman who said in reply to the certainty of death:

that as to hanging, she thought it no great Hardship, for, were it not for that, every cowardly Fellow would turn Pyrate, and so infest the Seas, that Men of Courage must starve: - That if it were 
put to the Choice of the Pyrates, they would not have the Punishment less than Death, the Fear of which, kept some dastardly Rogues honest; that many... would rob at Sea, and the Ocean would be crowded with Rogues, like the Land, and no Merchant would venture out; so that the Trade, a little Time, would not be worth following (125).

Love had little to do with it. Mary Read started a squabble with the very seaman that I was to duel and set him right by sword and pistol, killing him "on the spot" (124). Maybe she did it for me, but maybe she did it for herself. She was always better with the pistol, having worked as a soldier before leaving the landlubber life. She enjoyed a good fight. She loved a good fight.

Mary was put on trial, and pleaded her belly. She would not reveal the name of her lover, "but, said he was an honest Man, and had no Inclinations to such Practices, and that they both resolved to leave the Pyrates, the first Opportunity, and apply themselves to some honest Livelihood" (125).

We lay upon the deck at night, arms clasped around our beardless necks, and we would vow to leave this life behind, and have a piece of property between us as husband and wife, and lead an honest life. More rum punch Mary! And more rum punch Geoghan! Forget all that and toast to tomorrow. We will get a sloop together and sail the seas forever!

In that famous Pirate trial they found Mary Read guilty. As a last resort she pleaded her belly, but a physician would need to confirm it. I had at this time taken up at the Inn, visiting the trial with the rest of the mob every morning. A rap on my door woke me, would I come to examine the Pirate women? They had pleaded their bellies and needed confirmation. I threw on my greatcoat and ran to the courthouse. A lace untied, then tied again.

I could not cut Mary free from her rocky prison, she drowned in sadness.

The islanders are swimming and rowing towards our sloop. I want to feel the sand between my toes, I want to feel sweet nectar in my throat.

The cutlass slices through the clean throat and catches under the jawbone.

A woman hangs like a hooked codfish from the prow of the ship.

I want my fictional women to survive, to conquer, to come out vic- 
torious, however 'unrealistic' their ends may be.

- Aritha Van Herk "Of Viscera and Vital Questions," Language in her Eye (274)

Writes Stanley: "Of course, we will never know how women pirates feel and felt since this has never been described by the women themselves or by people in search of authenticity rather than sensationalism. But we can put ourselves in these sea-brigands' sailcloth breeches and imagine" (48).

"[Defoe] wrote for no interest other than truth." (West 177)

I am telling you stories, I am telling you lies.

\section{Notes}

1 "Every time that a woman whistles, the heart of the Virgin bleeds" Seafaring proverb. Superstition held that every time a woman whistles, a sailor drowns (Klausmann 17). Cooks on ships, however, were ordered to whistle when cooking, to assure the crew that none of the scarce rations were being consumed during preparation.

${ }^{2}$ Miranda: see William Shakespeare's The Tempest. Margaret Barclay: Scottish witch reputed to have sunk a ship by throwing a wax model into the sea (Klausmann 16). Mother Carey: Mater Cara Sea-Witch of English Folklore (Klausmann 14). Elspeth MacEwan: Last witch burnt in Scotland, 1698, Kirkcudbright. Maria Cobham: Female pirate. Bessy Miller: Orkney Island wind-seller (Klausmann 16).

${ }^{3}$ Selkie/Silkie/Selk: Seal People of West Coast Scottish folklore; human offspring of the pairing of a human, and a seal in the form of a human. Selkies can transform themselves into humans, and back into seals. Duncan Williamson in Tales of the Sea People posits that the Selkie legends provided comfort to families whose men had gone missing while fishing. Williamson's own grandmother used a piece of sealskin to predict the weather: hair rising meaning storms, hair smooth meaning calm.

${ }^{4}$ As a child, I spent many summers in Kirkcudbright, Scotland. One time, my mother, grandmother, uncle, aunt, cousins, brother, sister, and I walked for miles across raw-sienna coloured sand to see the old shipwreck. It looked as massive as the bones of a giant elephant turned on its back; picked of its carrion by the myriad seagulls. Other children had gathered and were playing amongst the spines. Despite the sun-dappled 
pools, the laughter, the satisfactory squelch of sand sucking at our feet, I'll never forget the feeling of utter desolation that draped over me like the verdant seaweed clinging to the tines of the wreck.

${ }^{5}$ Again, as children in Kirkcudbright, my sister, brother, cousins and I would visit the smuggler's caves. The whereabouts to these caves seemed to be a secret shared only by us, although in hindsight I can't imagine that many locals or tourists would be interested in exploring dank, bat-infested, guano-carpeted caverns. Some of the caves could only be squeezed into by the smallest of us; my sister, age sixteen, got stuck in the mouth of one. The caves were lined with shelves, sadly for us longempty of their wares. When my Grandmother passed away, my brother returned to Kirkcudbright, and to the caves. He thought it would be amusing to leave my Grandfather's medical skeleton in one of the caves to frighten the next adventurers, but our Uncle vetoed the plan. The bones were packed up into their numbered boxes and sent to a medical school in Edinburgh.

${ }^{6}$ I recall my younger brother entering a crab-catching festival at Kirkcudbright harbour. Crab lines have box-shaped reels, much like a kite. The trick is to get the crab to grab the bate by the claw and then to gently reel it in. It proves tricky to find a crab both gormless and tenacious enough to make the passage up to the dock; my brother did not catch a thing. Of course, ask him and you may get a different story.

${ }^{7}$ The name Geoghan has been bestowed upon both males and females throughout my Scottish paternal grandmother's lineage, hence I thought it would make an interesting name for my character. Looking up the name on the world wide website, The (Mac)Goeghegan/MacEochagain/ Geoghegan Homepage at http://homepage.tinet.ie/ eddiegeo/geoghegan/page8.html, I learnt that it is a Celtic-Irish name. Notes Eddie Geoghegan, creator of the site: "None of the above [versions of the name] should be taken as absolute, especially in the case of emigrant families. All sorts of strange and wonderful things happened to surnames when they left their homeland for faraway shores. Many emigrants from Ireland could not read and write and were reliant on others to register their names on official forms. Geoghegan was never the most common of names and so it has been moulded into the most improbable forms over the centuries." Apparently the version of the name circulating in my family, Geoghan, is the most common misspelling.

8 "Why was the work ethic absent from what was famed as the most 
Protestant town in Scotland [Kirkcudbright], where during the reign of Charles II two young women were staked to the seashore and drowned at high tide rather than disavow their solemn Covenant?" (West 377).

${ }^{9}$ The last recorded witch-burning in England was in 1685, but the last recorded case in Galloway, Scotland was in 1698 in the town of Kirkcudbright. Elspeth MacEwan was pronounced guilty of "a compact and correspondence with the devil, and of charms and of accessation to malefices". Earlier, in 1659 in neighbouring Dumfries, nine witches were strangled and burned on the banks of the Nith. The witch of Irongray "was observed to predict shower or sunshine at certain periods, which predictions often came to be realized." Sealed into a tar-coated barrel set aflame, she was rolled into the waters of the Cullen. This information can be found on the world wide web at http://members.aol.com/skyelander/witch2.html.

${ }^{10}$ A sign of scurvy.

11 Perched on my grandmother's garden wall, I would watch the teenagers dancing at the townhall next door every Friday night. The year was 1977, and although. I was a teenager myself, my grandmother did not let me go to the dances. I never disobeyed her, much to my regret.

${ }^{12}$ On my last visit to Kirkcudbright the Brixton riots were on television and my grandmother watched fearfully through the curtains at the 'louts', or punk-rockers, sitting on the church wall across the road. I was not allowed to venture out at night, and I did not venture out at night, although I wanted to. I am not the stuff that pirates were made of! I have not been back to Kirkcudbright. Last year I met a young fellow from Dumfries, who told me that there were no jobs to be had in Kirkcudbright.

\section{Works Cited}

Cixous, Helene. Stigmata: Escaping Texts. Trans. Catherine A.F. MacGillivray. London: Routledge, 1998.

Hebdige, Dick. Subculture: The Meaning of Style. New Accents. London: Routledge, 1988.

Klausmann, Ulrike, Gabriel Kuhn and Marion Meinzerin. Women Pirates and the Politics of the Jolly Roger. Montreal: Black Rose Books, 1997.

Johnson, Captain Charles. Formerly attributed to Defoe, Daniel. A General History of the Robberies and Murders of the Most Notorious Pyrates. William Graves, ed. New York: Garland Publishing, 1972. 
Marlatt, Daphne. Ana Historic. Concord: Coach House Press, 1988.

--. Readings From the Labyrinth. Ed. Smaro Kamboureli. The Writer as Critic: VI. Edmonton: NeWest Press, 1998.

Scheier, Libby, Sarah Sheard and Eleanor Wachtel, eds. Language in Her Eye: Writing and Gender - Views by Canadian Women Writing in English. Toronto: Coach House Press, 1990.

Stanley, Jo, ed. Bold in Her Breeches: Women Pirates Across the Ages. Pandora. London: Harper Collins, 1995.

Van Herk, Aritha. In Visible Ink: Crypto-frictions. Edmonton: NeWest Press, 1991.

West, Richard. The Life and Strange Surprising Adventures of Daniel Defoe. Flamingo. London: Harper Collins, 1997.

Williamson, Duncan. Tales of the Seal People. New York: Interlink Books, 1992. 